\title{
Developing Social Interaction Skills with Game Technology
}

\author{
Lidya Oktorina Kusuma Sakti \\ lidyaoktorina@gmail.com \\ PT. Sinar Sosro, Bekasi \\ Septyana Hardianti Yunanto \\ septyana93@gmail.com \\ Data Driven Systems, Semarang
}

\begin{abstract}
Socialization is an essential process in human living. Human is a social creature which can not live without the help of others, so human needs friends to communicate and interact with each other to make a living better. Through socialization, a human can build good characters to care with others and their social life circle. Nowadays, game technology has already fast and sophisticated. People use game not only for entertainment media but for education media and media to prevent social problems in the society. With game technology, the game will be expected to reduce the lack of socialization in the society. It can help someone to open his/herself and develop social skill by interacting in social society using the social feature in the game.
\end{abstract}

Keywords - game, social interaction skills, social problems

\section{INTRODUCTION}

Socialization is an essential process in human living. Human is a social creature which can not live without the help of others, so human needs friends to communicate and interact with each other to make a living better. Through socialization, a human can build good characters to care with others and their social life circle.

Besides the importance of the socialization process, there are people that lack socialization skill. They tend to become someone who closed from outside and preventing themselves from social events [1]. If someone has a lack social skill, he/ she will have a bad character development; they will be difficult to get help from others and think that they can live without others, even they can have a thought that social norms are not suitable with theirs [2]. Lack of social skill will have another impact such as psychological well-being, they can get stress because of bearing all of their problems by themselves [3].

Nowadays, game technology has already fast and sophisticated. People use game not only for entertainment media but for education media and media to prevent social problems in the society. With game technology, the game will be expected to reduce the lack of socialization in the society. It can help someone to open his/herself and develop social skill by interacting in social society using the social feature in the game.

\section{METHOD}

\section{A. Definition of Social Interaction}

According to Peter L Berger, social interaction is a process to become a member of the community and participate in the social living with others member in the community. Besides of that, according to Soejorno Soekanto, social interaction is a human process to learn social norm and value, so social interaction can make a human become a part of social living with a member of the community and live based on habit, rule, norm, and value in the community [4]. Social interaction is defined by Vander Zande as a process like thinking, feeling, and behaving to make someone take an effective role in the community [5]. 


\section{B. Interaction Agent \\ 1. Family}

The family is a social interaction agent that is important to develop social interaction in a person. Family can give someone emotional support, social norm and comfort [6].

\section{Friends}

Friends is a social group that has mutual social interaction [6].

\section{Media Technology}

Media technology can be used as a communication tool for people. One of the media technology that already grows up is game technology that has a connection with social media [6].

\section{Definition of Game Technology}

According to Nilwan, Agustinus (1996), from his book "Pemrograman Animasi dan Game Profesional” (Animation and Game Professional Programming), the game is a computer game which has been made with technical and animation method. Beside of that, the game is a complex activity which follows rule and culture and can be played individually or in a group to get the goals [7]. And according to Retno (2011), the game can be referred to as a deciding and players action arena; there will be targets that have to be reached by players. The game in real life can sharpen players analysis to process information and action faster [8].

\section{RESULTS AND DISCUSSION}

\section{A. Pet's Island Social Game}

Pet's Island is a popular mobile social game that can be downloaded via Play Store. Some YouTubers in Indonesia already reviewed this game.

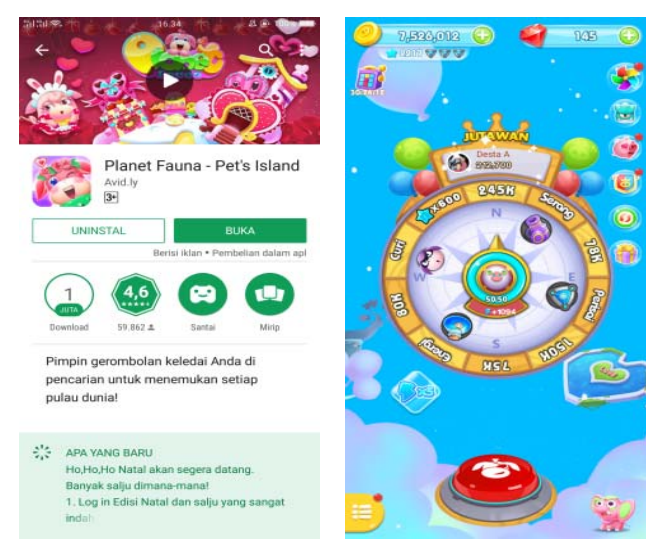

Figure 1.Display the PET'S ISLAND SOCIAL GAME

This game has a goal to build buildings on an island. In this game will be provided with a rolling wheel. If we roll this wheel, we will get chips that can be used to buy the building, guessing “jutawan” or millioner that have the more chips, attack other people's or friend's island, and we could get "perisai" or shield to defend our buildings from other people. When the wheel is being rolled, the energy in the wheel will decreasing and will increase once a time in 6 hours.

Beside building islands, there will be a group or clan with a maximum of 30 persons per clan. In this game will have some events and clan can unite and fight and get the top 100 ranks to get the prizes at the end of an event. Some other prizes can be got with filling a bottle with other players. In these events can make players learn solidarity so they can get a good rank and get more prizes.

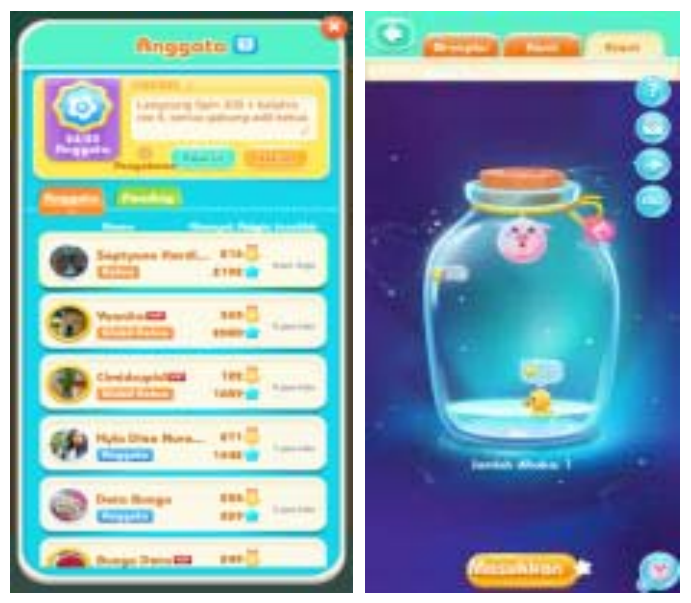




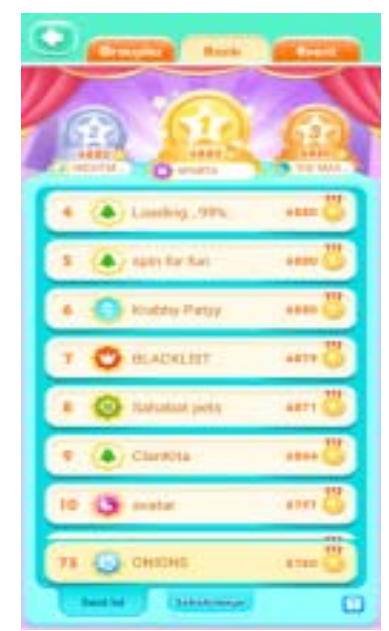

Figure 2. Game view to get points and share with other friends

\section{B. How to Play Pet's Island}

Player has to login with a Facebook account, and automatically all of the player's friend on Facebook will become player's friend on the game and connected to others.

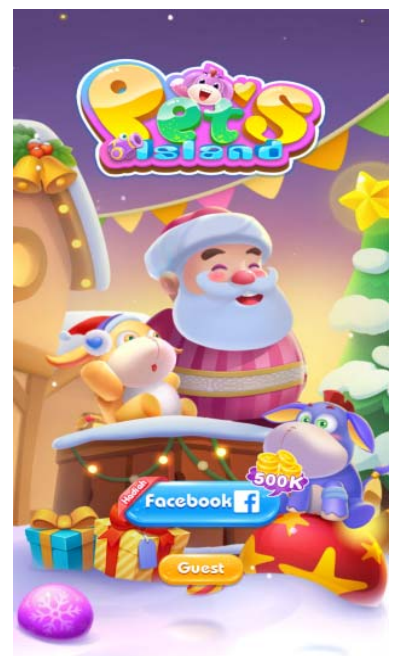

Figure 3. Connect to Facebook can play with other friends

The main goal of this game is to build all the buildings on one island. Every week there will be a new island. A player who wants to build a building must be having chips from spinning wheels. Besides building, players have to guard their building against another player using "perisai" or shield that can be got from spinning wheels too. Players can steal another player's chips. Every building has the different price of chips according to level, so players have to gather chips as much as they can.
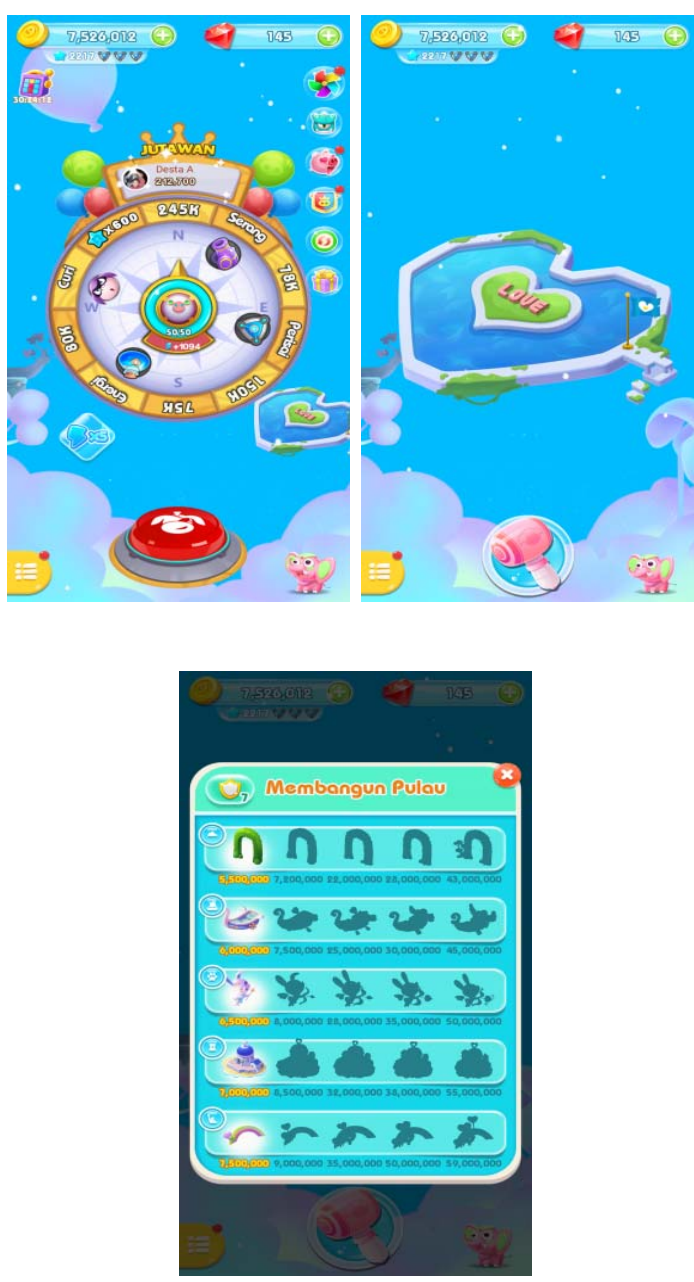

Figure 4. in-game display to build the island

In the above picture, we can see the star icon in the left corner. The icon shows the player's level (on the picture is 2217). This level contains the last island. To wait for a new island, players have to gather prizes from a tree and completing the puzzle to claim the prizes.
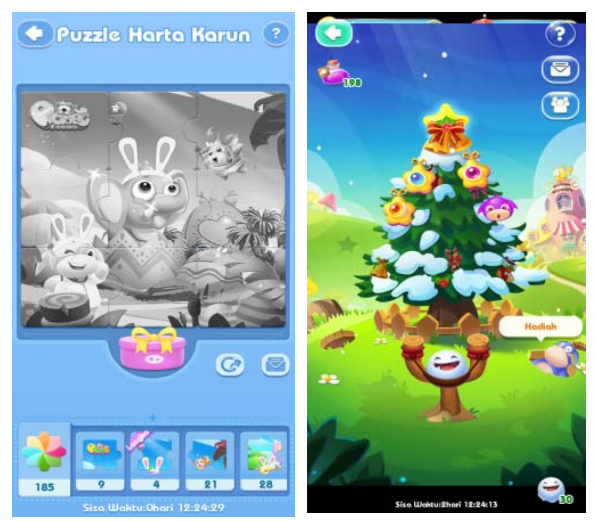


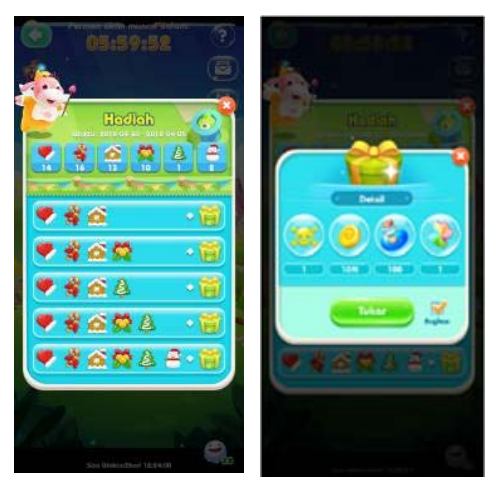

Figure 5. Puzzle and tree game display to get points

\section{The Impact of Pet's Island Game}

Pet's Island game have to make players gather energy and chips to build on islands. Energy and chips can be got from completing the puzzle and exchanging prizes from the tree. However, there are some puzzle and prizes which can be hard to get.

With this difficulty, the player has to ask help from another player that have to be their friends from Facebook or Game ID. These ways, player can complete the puzzle and get the prize.

Pet's Island has an official group on Facebook that can be their media to exchange items or to ask help on the game. Some players can share their tips on how to building faster or asking to join their clan and some others activity from the game.

When players are exchanging their piece of puzzle or prizes from the tree, they can practice their skill in negotiation until both of them agree to exchange. Players can learn to interact with other players and learn to be a good negotiator to get their need. Besides that, using clan players can communicate with others to manage their clan.

\section{CONCLUSION}

Pet's Island game can develop social interaction and make players interact with other players because this game needs other players or friends to exchange and reach their goals. Players need to find another friend to interact and negotiate with another player so they can

\section{ACKNOWLEDGMENT}

LidyaOktorinaKusumaSakti and SeptyanaHardiantiYunanto is student who received a scholarship from Ministry of National Education of Republic Indonesia

\section{REFERENCES}

[1] Alekhine, Riswandi. (2017). “Apaitu Introvert, Bagaimana cara berinteraksi dengan mereka?” [Online]. Available: https://psyline.id/apa-ituintrovert/.[Accessed June-28-2018].

[2] Agiesta, Fellyanda Suci. (2017). "Inilah yang Terjadi Jika Kamu Kurang Bersosialisasi” [Online]. Available: https://www.winnetnews.com/post/inila h-yang-terjadi-jika-kamu-kurangbersosialisasi.[Accessed June-28-2018].

[3] (2016). "Inidia 8 Penyebab Seseorang Sulit Bergaul” [Online]. Available: http://www.gelombangotak.com/Ini-dia8-Penyebab-Seseorang-Sulit-

Bergaul.htm. [Accessed June-28-2018].

[4] (2015). "Pengertian Sosialisasi Menurut para Ahli” [Online]. Available: http://www.areabaca.com/2015/12/peng ertian-sosialisasi-menurut-paraahli.html. [Accessed June-29-2018].

[5] Rainer, Dedi. (2017). “26 Pengertian Sosialisasi Menurut Para Ahli Terlengkap” [Online]. Available: http://www.spengetahuan.com/2017/08/ 26-pengertian-sosialisasi-menurut-paraahli.html.[Accessed June-29-2018].

[6] Nurullkk. (2017). “Agen-agen Sosialisasi” [Online]. Available: https://www.slideshare.net/Nurullkk/age n-agen-sosialisasi/.[Accessed June-302018].

[7] Nilwan, Agustinus. Pemrograman Animasi dan Game Profesional. Jakarta: Elex Media Komputindo, 1998.

[8] W. Ramansyah, "PENGEMBANGAN GAME EDUKASI 'AKSARA JAWA' BERBASIS UNITY UNTUK SISWA KELAS 3 SDN MULYOARJO 3 LAWANG." 